\title{
OBSERVAÇÕES ACERCA DA PEÇA DE PEDRO CALDERÓN DE LA BARCA, A VIDA É SONHO
}

Jorge de Freitas*
* defreitasjorge@yahoo.com.br

Jorge de Freitas. Mestrando em Estética e Filosofia da Arte pela Universidade Federal de Ouro Preto (UFOP/ bolsista CAPES).
RESUMO: A proposta deste artigo é discutir alguns pontos da peça $A$ vida é sonho, do dramaturgo espanho Pedro Calderón de La Barca, atentando para pontos de convergência entre a dramaturgia de Calderón e questões teológicas e filosóficas. Buscaremos, no decorrer do artigo, traçar algumas comparações com a primeira das Meditações Metafísicas, de Descartes, a teoria sobre o Barroco de Walter Benjamin, e o conceito de trágico abordado por Peter Szondi.

PALAVRAS-CHAVE: Calderón de La Barca, Descartes, Benjamin, Szondi, Barroco.
RESUMEN: El propósito de este artículo es discutir algunos puntos de La vida es sueño, una obra de teatro del dramaturgo españolPedro Calderón de la Barca, señalando los puntos de convergencia entre el drama de Calderón y cuestiones teológicas y filosóficas. Buscaremos, en todo el artículo, hacer algunas comparaciones con la primera de las Meditaciones Metafísicas, de René Descartes, la teoría del Barroco de Walter Benjamin y el concepto de lo trágico abordado por Peter Szondi.

PALABRAS CLAVE: Calderón de la Barca, Descartes, Benjamin, Szondi, Barroco. 
1. LIMA \& VALE. Apresentação. $A$ vida é sonho, p. 12

2. É possível avistar a forte influência da obra de Santo Agostinho, acerca da "Cidade dos Homens" afundada em trevas e pecado e a Cidade de Deus onde os eleitos viveriam envoltos pela Graça Divina. envoltos pela Graça Divina.

3. LIMA \& VALE. Apresentação. $A$ vida é sonho, p. 13.
A peça do dramaturgo e poeta espanhol Pedro Calderón de La Barca A vida é sonho, publicada em 1636 na reunião de suas peças intitulada Comédias, de temática barroca e cristã visa oferecer um modelo de prudência para o príncipe cristão. Calderón membro da corte espanhola e dramaturgo oficial do rei Felipe IV, inserido em uma Espanha fortemente católica teve, segundo Luís Filipe Lima e Ricardo Vale, autores da "Introdução" de A vida é sonho (2009) que acompanha a edição brasileira lançada pela editora Hedra, a figura e a obra "transformados em modelos do que então se supunha o século XVII e a cultura ibérica no tempo da política católica da Casa de Áustria e da violenta intervenção contra reformista". ${ }^{1}$ Deste modo, as peças de Calderón somam-se ao arcabouço de combate à Reforma Religiosa proposta pela Contra-Reforma promovida pela Igreja Católica, ao adotarem procedimentos peculiares à temática barroca, como o exagero, o abuso de ornamentação que delimitam a sua construção e, principalmente, que esta vida é ilusão e o que importa é a "verdadeira" vida, na ascese ao céu após a morte. ${ }^{2}$ Ademais, as peças calderonianas, dentre elas $A$ vida sonho, assumem o aspecto didático de orientação das virtudes cristãs, em especial, a prudência e o perdão.

"O sonho como metáfora da vida era comum na obra de Calderón", ${ }^{3}$ atestando para o entendimento comum do século XVII de que "a vigília, a ação humana, não passava de ilusão e que como os sonhos, que se dissipam com o dia, a vida se dissipara com a noite ou o sono da morte", ${ }^{4}$ ou seja, a realidade mundana em que se insere o sujeito fragmentado do século XVII, inerte em uma época de derrocadas da experiência humana e religiosa, é uma realidade ilusória e de provações do espirito cristão, cuja finalidade determinar quais serão aqueles que se ao não sucumbirem às fantasias e aos vícios da realidade mundana, juntaram-se ao Criador no Reino dos Céus. Portanto, para a doutrina católica presente na Península Ibérica, a vida era sonho, ilusão passageira e época de provação. Onde, nessa realidade de ilusão, "tudo era figura e imagem de Deus e efeito da Criação" ${ }^{5}$

Neste contexto religioso que aguarda a salvação por meio da vida eterna, cujo ato de criação enquanto ser humano advinha diretamente da Criação Divina, restava orientar-se a vontade segundo os designíos das "boas leis e dos bons exemplos, a fim de escolher entre erros e acertos" . ${ }^{6}$ Calderón, através de suas peças, contribuirá para a disseminação dos dogmas cristãos, em especial, ao determinar na figura do governante, os modelos de conduta que correspondiam às doutrinas da fé cristã, como visto em $A$ vida é sonho, onde o bom governante era "aquele que não se deixava levar pelos desejos, pela ira, pelas ambições, pelos sonhos”. ${ }^{7}$ É possível, atentarmos para o modelo aristotélico de virtude, o qual
4. LIMA \& VALE. Apresentação. $A$ vida é sonho, p. 13.

5. LIMA \& VALE. Apresentação. $A$ vida é sonho, p. 16.

6. LIMA \& VALE. Apresentação. $A$ vida é sonho, p. 16.

7. LIMA \& VALE. Apresentação. $A$ vida é sonho, p. 18.
EM TESE $\quad$ BELO HORIZONTE $\quad$ v. $19 \quad$ N. $1 \quad$ JAN.-ABR. $2013 \quad$ FREITAS. Observações acerca da peça de Pedro Calderón de La Barca [...] $\quad$ P. 247-261

\section{Crítica Literária, outras Artes e Mídias}


8. LIMA \& VALE. Apresentação. $A$ vida é sonho, p. 27. É inegável o vocabulário aristotélico adotado para a descrição da prudência como virtude necessária à constituição do bom governante. determinava o controle das paixões através da temperança onde esta virtude ética teria por fim, a posição de assentar-se como a justa medida entre os excessos e as faltas das paixões que cercam os indivíduos.

Em $A$ vida é sonho, outra virtude no sentido aristotélico também é posta em cena, a saber, a prudência. O príncipe cuja tarefa é a de espelhar-se como modelo e dirigir corretamente a vida dos homens, através de ações que busquem a verdade e o bem comum, deve constituir-se virtuosamente prudente. Deste modo, a prudência era vista

como o controle das paixões e dos sentidos, como boa eleição e juízo, era a virtude capital, a fonte das demais, para o bom governo de si e da hierarquia política. Um bom príncipe precisava ter auto-governo para poder governar com justiça, buscando a felicidade não nas glórias terrenas, mas nas eternas, que consistiam em proporcionar a boa ordem dos estados civis que lhe estavam sujeitos, garantindo o bem comum, figura temporal do sumo bem, enquanto se espera o fim do mundo, quando os bons reis e bons súditos, vivos e mortos, esperaram ter salvos corpos e almas da danação eterna.

A vida é sonho se passa na corte de Basílio, rei da Polônia, dividindo-se em três jornadas para contar a história do príncipe polonês Segismundo. Na primeira jornada, foi profetizado em sonho pela esposa do rei, o nascimento de um herdeiro real capaz de romper-lhe a barriga durante o parto e trazer infortúnios e desgraças ao reino polonês. No parto, o início do presságio se cumpre, o nascimento de Segismundo leva a sua mãe a morte. Atormentado pelo presságio de ter o seu reino dividido e assolado por um "monstro em forma de homem" o rei, certo da validade da profecia, amparado pelos sonhos e pela crença na astrologia, ordena a construção de uma torre para aprisionar o "mal nascido". ${ }^{10}$

O príncipe Segismundo aprisionado na torre nada tem de conhecimento de sua condição régia, porém o rei Basílio, questionando-se sobre a legitimidade do presságio, ou seja, questionando-se sobre a determinação do destino do reino assentado na legitimidade dos astros sobre o livre arbítrio, este condição sine qua non do amor divino, resolve por a prova o presságio e libertar Segismundo por um dia de sua situação de cativo, conferindo-lhe a legitimidade de um príncipe. O plano de Basílio, conferido a Clotaldo, o velho criado que toma conta de Segismundo, consiste em adormecer o príncipe em sua prisão através de uma bebida composta por uma mistura de ervas e, adormecido seria levado ao palácio real, de modo que, quando Segismundo acordasse, estaria nos aposentos do palácio real cercado por criados e coroado como o príncipe da Polônia.
9. CALDERÓN DE LABARCA. vida é sonho, p. 45 .

10. CALDERÓN DE LA BARCA. $A$ vida é sonho, p. 46.

\section{Crítica Literária, outras Artes e Mídias}


11. CALDERÓN DE LA BARCA. $A$ vida é sonho, p. 55.

12. CALDERÓN DE LA BARCA. $A$ vida é sonho, p. 61.
Na segunda jornada, Segismundo, longe da prisão e como príncipe polonês, espanta-se com a situação em que se encontra, questionando-se sobre a consistência da realidade que o circunda, não sabe se está a sonhar ou acordado, se realmente é Segismundo ou não. Cercado por criados que o oferecem as regalias reais, o príncipe acredita que a melhor opção é aceitá-los, sem discutir. A entrada de Clotaldo na cena e a mudança de seu tratamento, desperta a inquietação de Segismundo na seguinte questão: "é Clotaldo. Como será possível distinguir-me com tal respeito que na prisão me maltratava? Que se passa comigo?". ${ }^{11}$ A resposta para a inquietação de Segismundo advém de Clotaldo que lhe revê-la a sua ascendência real, como príncipe e herdeiro do reino da Polônia. Imediatamente, o príncipe polonês, tomado pela ira, condena o pobre Clotaldo à morte. Neste ínterim, a ira de Segismundo é direcionada a todos ao seu redor, incluindo um dos criados que é atirado pela janela pelas mãos do príncipe tirano e, a Astolfo, seu primo e duque de Moscou. Com a chegada de Basílio ao recinto, surgem às lamentações acerca da falta de prudência de Segismundo e o exaspero de seu ânimo capaz de atirar o pobre criado pela janela, bem como, a conclusão por parte de Basílio da confirmação de todos os presságios, "és bárbaro e atrevido; cumpriu o céu o que ditou". ${ }^{12}$
Após os desmandos de Segismundo, sobretudo, no que diz respeito à figura de Clotaldo que aconselha o príncipe a ser mais agradável e prudente se quiser reinar, pois, talvez tudo ali não passe de um sonho. O príncipe, desconsiderando os conselhos do velho, com a adaga em punho parte par cima de Clotaldo para matá-lo. Acontecimento que, no entendimento de Segismundo, provaria se a situação em que se encontrava era um sonho ou a própria realidade. A contenda termina com a chegada de Astolfo que impede o assassínio de Clotaldo, e, pouco depois, com a intervenção do rei Basílio.

$\mathrm{Na}$ cena seguinte, adormecido, preso aos grilhões na torre e vestido com as suas habituais vestimentas de prisioneiro, Segismundo desperta de um sonho onde derrotava o próprio pai em sua vingança. Despertando, mais uma vez questiona-se onde se encontra. Clotaldo aproxima-se, dizendo-lhe que já dormiste por muito tempo e está na hora de acordar, O príncipe conta-lhe do estranho sonho que mais parecia à pura realidade, onde era o príncipe herdeiro do trono da Polônia e todas as desventuras que havia cometido. Clotaldo reforça a condição onírica do estado de Segismundo, e atribui-lhe um prudente conselho, que mesmo em sonho deve sempre priorizar as boas ações. Ao fim desta segunda jornada tem-se o único monólogo de toda a peça, donde Segismundo profere as seguintes sentenças:

\section{Crítica Literária, outras Artes e Mídias}


É certo; então reprimamos

esta fera condição,

está fúria, esta ambição,

pois pode ser que sonhemos;

\section{[...]}

Que é a vida? Um frenesi.

Que é a vida? Uma ilusão,

uma sombra, uma ficção;

o maior bem é tristonho,

porque toda A vida é sonho,

e os sonhos, sonhos são. ${ }^{13}$

Aqui, Calderón revela o forte aspecto doutrinário cristão da peça, é necessário reprimir as paixões da vida mundana, a condição de fera que deturpa os ânimos e produz a realização de ações condenáveis, a fúria, a ambição dos que se entregam à vida terrena devem ser controladas, amenizadas pelas doutrinas da prudência, pois pode ser que a vida não passe de um mero sonho, e tais ações condenáveis afastaram o ser do caminho justo daquele prudente que herdara o reino dos céus. Ao determinar que essa vida terrena, mundana é uma ilusão, uma sombra da verdadeira vida, e que "o maior o bem é tristonho", ou seja, o acordar para a morte, o dramaturgo acentua o caráter irreal da realidade terrena e atesta para a morte como "o destino para o qual corre a vida fugaz no mundo temporal: a própria morte e o julgamento do Eterno, e não as imagens fingidas (semelhantes ao sonho dormindo) que são as ações e vontades humanas, como querer reinar". ${ }^{14}$

$\mathrm{Na}$ terceira jornada, Segismundo, preso na torre, é abordado por soldados que ao saberem de sua existência planejam uma conspiração para derrubar o rei Basílio e instituir no trono o príncipe renegado. Nesta jornada, Segismundo parece ter aprendido com os prenúncios de seu "sonho" modifica a sua postura com relação à segunda jornada. Aceita participar do plano de conspiração proposto pelos soldados, mas ao fim, proporciona uma reviravolta e com as ações dirigidas pela prudência evita a iminente guerra civil, e no caminho da justiça "supera o prognóstico nefasto dos sonhos de sua mãe e dos astros". ${ }^{15}$

A lição que a peça calderoniana deixa é a que o príncipe mesmo criado e educado como uma fera aprisionada, aprende que se quiser servir de exemplo e governar o reino, tem de adotar as ações mais prudentes e seguir os seus caminhos seguindo o "bom uso do livre-arbítrio, em conformidade com a reta razão das coisas que concerniam à sua posição, domando a sua inclinação natural e tornando-se um homem nobre" ${ }^{16}$ Ao fim, o prudente Segismundo pede perdão ${ }^{17}$ pelas
14. LIMA \& VALLE. Apresentação. $A$ vida é sonho, p. 21.

15. LIMA \& VALLE. Apresentação. $A$ vida é sonho, p. 28.

16. LIMA \& VALLE. Apresentação. $A$ vida é sonho, p. 28.

17. Vale ressaltar que o ato de pedir perdão, e principalmente, o ato de perdoar constituem núcleo da doutrina cristá, juntamente com a crença da ressurreição do espírito na vida eterna.
EM TESE BELO HORIZONTE $\quad$ v. $19 \quad$ N. $1 \quad$ JAN.ABB. $2013 \quad$ FREITAS. Observações acerca da peça de Pedro Calderón de La Barca [...] $\quad$ P. 247-261

\section{Crítica Literária, outras Artes e Midias}


18. CALDERÓN DE LA BARCA. $A$ vida é sonho, p. 94

19. DESCARTES. Meditações metafísicas, p. 31. faltas cometidas e reconhece que a felicidade humana na vida terrena é passageira, ilusória e passa-se "como um sonho/ [...] pedindo, de nossas faltas/a todos os que me ouvem/ perdão, pois em peitos nobres/o perdão é flor de ouro". ${ }^{18}$

A vida é sonho? Os sentidos nos enganam? É possível determinar quando estamos a sonhar e quando estamos acordados? Existe um gênio maligno capaz de confundir as nossas percepções? Estes são os temas abordados pelo filósofo francês René Descartes (2000) na Primeira Meditação das suas Meditações metafísicas. Dentro desta atmosfera duvidosa que Descartes intitula como "Das coisas que se podem colocar em dúvida" é realizada a meditação crítica acerca das opiniões antes tidas como verdadeiras pelo filósofo e, deste modo, é colocado em questão o processo que leva ao conhecimento das coisas.

Descartes inicia o processo da dúvida ao determinar que toda a apreensão do conhecimento que recebeu até o momento, mesmo o "mais verdadeiro e seguro, aprendi-o dos sentidos ou pelos sentidos; ora algumas vezes experimentei que tais sentidos eram enganadores, e é de prudência jamais confiar inteiramente naqueles que uma vez nos enganaram". ${ }^{19} \mathrm{Ou}$ seja, os sentidos podem nos enganar, é necessário pôr em dúvida os dados que são apreendidos por eles. Porém, existem outros dados sensíveis, aos quais não se pode colocar em questão, o exemplo levantado pelo filósofo é o seguinte, "por exemplo, que estou aqui, sentado perto do fogo, vestido com um roupão, com este papel entre as mãos, e outras coisas dessa natureza. E como é que eu posso negar que estas mãos e este corpo sejam meus?". ${ }^{20}$ Descartes considera que colocar em dúvida uma situação como esta seria adotar a posição da loucura.

No segundo momento da dúvida, o filósofo busca pôr em questão situações que se apresentam inquestionáveis perante os sentidos, tão reais quanto o exemplo levantado anteriormente, mas que se apresentam quando estamos dormindo, portanto no domínio dos sonhos. Os sonhos que, mostrando-se, por vezes, tão reais quanto à realidade em si mesma atentam para a questão: o que garante que a realidade não passe de um sonho? Uma vez que o próprio filósofo admite

ter sido frequentemente enganado, quando dormia, por semelhantes ilusões. E, detendo-me nesse pensamento, vejo tão manifestamente que não há indícios concludentes nem marcas bastante certas por onde possa distinguir nitidamente a vigília do sono, que fico muito espantado, e meu espanto é tal que é quase capaz de persuadir-me de que durmo. ${ }^{21}$

Qual o mecanismo adotado pelo filósofo para sanar essa questão, a saber, como diferenciar a realidade, ou a vigília,
20. DESCARTES. Meditações metafisicas, p. 31

21. DESCARTES. Meditações metafísicas, p. 33.
EM TESE
BELO HORIZONTE
v. 19
N. 1
JAN.-ABR. 2013
FREITAS. Observações acerca da peça de Pedro Calderón de La Barca [...]
P. $247-261$

\section{Crítica Literária, outras Artes e Mídias}


22. DESCARTES. Meditações metafísicas, p. 33.

\section{DESCARTES. Meditações} metafísicas, p. 35.

24. DESCARTES. Meditações metafísicas, p. 36. do sono? Duvidar das representações oníricas, consentido que estas "representadas no sono são como quadros e pinturas, que só podem ser formadas à semelhança de algo rea e verdadeiro", ${ }^{22}$ ou seja, aquilo que representamos no sonho deve partir de algo indubitavelmente verdadeiro, existente no real. Pois, o conteúdo onírico nasceria das relações experiências que travo com essas verdades reais inquestionáveis, onde, mesmo que a obra da representação onírica seja puramente uma invenção de minha imaginação, as verdades referentes à matemática, por exemplo, sempre serão inquestionavelmente verdadeiras, segundo Descartes, "pois, esteja eu acordado ou dormindo, dois e três juntos sempre formarão o número cinco". ${ }^{23}$

O terceiro momento conhecido como o argumento acerca da existência de um Deus enganador ou gênio maligno, eleva a dúvida cartesiana ao limite por colocar em questão até mesmo as certezas matemáticas. Descartes põe em questão a existência de um Deus capaz de nos enganar, um gênio do maligno que talvez queira que "eu me engane todas as vezes que faço a adição de dois e três" ${ }^{24}$ algo que entraria em contradição com a máxima de um Deus soberanamente bom.

Ao elevar a dúvida ao limite, duvidando daquilo que antes considerava como verdadeiro, o filósofo luta contra as suas próprias opiniões que, por diversas vezes, retornam a sua consciência tendendo ao caminho do erro, não ao caminho do conhecimento. Por fim, Descartes supõe não a existência de um verdadeiro Deus enganador, no sentido religioso, mas sim, de um gênio do mal que empregaria toda a sua engenhosidade na produção de enganos, porém, o processo de meditação que coloca todo o conhecimento em dúvida força o espírito do filósofo contra "todas as astúcias desse grande enganador". ${ }^{25}$

São visíveis as proximidades entre as colocações cartesianas, em especial no segundo momento da dúvida, a saber, sobre a duvidosa situação entre estar acordado ou estar dormindo e a peça de Calderón.

Segismundo, o príncipe encarcerado, compartilha da mesma dúvida do filósofo, no início da terceira jornada, quando desperta novamente preso em seus grilhões, após ter sido concluída a trama de seu pai que visava questionar à profecia. Ainda despertando, em conversa com Clotaldo, Segismundo diz o seguinte: "Pois se o que vi, palpável e certo, era sonho. O que vejo agora é incerto. Será que não sonho que estou acordado?”. ${ }^{26}$

A esta colocação de Segismundo aproximamos a dúvida de Descartes em constatar que não existem traços conclusivos para distinguirmos entre a realidade e o sonho.
25. DESCARTES. Meditações metafísicas, p. 38.

26. CALDERÓN DE LA BARCA. $A$ vida é sonho, p. 71.
EM TESE
BELO HORIZONTE
v. 19
N. 1
JAN.-ABR. 2013
FREITAS. Observações acerca da peça de Pedro Calderón de La Barca [...]
P. $247-261$

\section{Crítica Literária, outras Artes e Midias}


27. DESCARTES. Meditações metafísicas, p. 38.
Porém, a linha que aproxima esses dois escritos é tênue, pois Descartes está consciente do processo racional de pôr em dúvida os fundamentos do conhecimento da realidade em oposição às ilusões oníricas. Todo o processo descarteano provém de um movimento argumentativo construído racionalmente de pôr em causa os dados do sentido, a existência das coisas e do próprio corpo. Já, o pobre príncipe Segismundo é a vítima de uma trama orquestrada por seu pai que lhe faz confundir as fronteiras entre a vigília e o sono. O sonho de Segismundo é a própria realidade, e não uma representação verossímil desta. Os acontecimentos que Segismundo presencia quando em sua condição de príncipe herdeiro, fora de seu calabouço, são de fato acontecimentos da realidade, ou melhor, da vida terrena O príncipe, diferentemente do escravo que "usufruía no sono uma liberdade imaginária”, ${ }^{27}$ usufrui de uma liberdade real no palácio, capaz até mesmo, de cometer atos terríveis.

As dúvidas até sobre as coisas mais indubitáveis, como o exercício da respiração, acompanham o príncipe, preso em uma artimanha que comprovaria uma determinação do destino, por toda a segunda jornada da peça estendendo-se po diversas meditações, como atesta quando desperta no ornamentado leito real:
BELO HORIZONTE
SEGISMUNDO - Estranho é tudo que vejo...

Tudo que sinto e respiro...

É espanto o que admiro...

é tanto que já não creio..

[...] Não sonho? Ou sim? É engano.

Bem sei que estou acordado.

Eu sou Segismundo... Não? ${ }^{28}$

Como já visto anteriormente, para Descartes toda a representação onírica provêm de sua existência concreta na realidade, as ilusões do mundo dos sonhos, nada mais seriam do que construções semelhantes a algo verdadeiro, e que "pelo menos essas coisas gerais, a saber, olhos, uma cabeça, mãos e todo o resto do corpo, não são coisas imaginárias, mas verdadeiras e existentes". ${ }^{29}$ Mas, o príncipe leva a dúvida às ultimas consequências ao duvidar de sua própria identidade, a estranheza que o rodeia e lhe vem por meio dos sentidos é tão cruel que se estende até as fronteiras da manutenção de sua vida, ao questionar o próprio ar que respira. Porém, ao fim, diferentemente do filósofo que articula a dúvida à compreensão racional da mesma, utilizando-se de artifícios racionais que demonstrariam verdades existentes e inquestionáveis, tanto na realidade quanto no sonho, o príncipe, por sua vez, entrega-se a ignorância, não questiona, apenas
28. CALDERÓN DE LA BARCA. $A$ vida é sonho, p. 94.

29. DESCARTES. Meditações metafísicas, p. 33.

\section{Crítica Literária, outras Artes e Mídias}


31. DESCARTES. Meditações metafísicas, p. 38.

30. CALDERÓN DE LA BARCA. $A$ vida é sonho, p. 54 deixa-se levar pela trama arquitetada contra ele, como atesta Calderón no fim da passagem em que Segismundo acorda, não como prisioneiro, mas como príncipe da Polônia:

Céu... o que é que foi mudado?

Quem fez a minha fantasia?

Oque fizeram de mim?

Que houve enquanto eu dormia?

Isto que eu sou terá fim?

Não sei...não posso saber..

Já não quero discutir...

Melhor deixar-me servir...

E seja o que há de ser. ${ }^{30}$

Nesta curiosa passagem que revela o não querer conhecer, e o abandono parcial da dúvida sobre a sua situação em que se encontra, atentaremos para a realização de uma interpretação que apresente uma afinidade com a meditação cartesiana, a saber, a questão colocada por Segismundo: "Quem fez a minha fantasia?" Mesmo sem saber que a fantasia fora criada por se pai, o rei Basílio, poderia o príncipe entender que toda a fantasia criada para lhe enganar, seria uma artimanha de um gênio maligno, cujo propósito seria desviá-lo da Providência? Um gênio maligno, nos termos de
Descartes, capaz de fazê-lo pensar "que o céu, o ar, a terra, as cores, as figuras, os sons e todas as coisas exteriores que vemos não passam de ilusões e enganos?". ${ }^{31}$ É plausível atentar para este ponto, se retomarmos o momento do despertar de Segismundo, que põem em dúvida até as coisas mais necessárias, como o ar que respira. E, o pobre príncipe, que cai trama orquestrada por seu pai, não possui o treinamento espiritual necessário para orientar o seu espirito para fora da dúvida, e certamente, ao renegar o dever de por em causa a realidade que o cerca, teve o juízo "desviado do caminho reto que o pode conduzir ao conhecimento". ${ }^{32}$ Ademais, a declaração de Segismundo "Não sei... não posso saber" talvez aponte para o sintoma de que toda a modificação de sua situação, de prisioneiro a príncipe, tenha sido realizada por uma força maior que vai para além de suas compreensões, por isso o benefício da ignorância adotado pelo príncipe.

O filósofo alemão Walter Benjamin (2011) dedica à primeira parte de sua obra Origem do drama trágico alemão, o capítulo "Drama Trágico e Tragédia”, a intenção de definir o gênero drama trágico, diferenciando-o, principalmente, das teorias que visavam normatizar a produção da tragédia. É viável atentar que o objeto principal de estudo do filósofo são as peças do drama Barroco alemão, estas de difícil acesso e quase sempre distantes dos modelos considerados
32. DESCARTES. Meditações metafísicas, p. 37.
EM TESE $\quad$ BELO HORIZONTE $\quad$ v. $19 \quad$ N. $1 \quad$ JAN.-ABR. $2013 \quad$ FREITAS. Observações acerca da peça de Pedro Calderón de La Barca [...] $\quad$ P. 247-261

\section{Crítica Literária, outras Artes e Midias}


por Benjamin como exemplos da tradição do teatro Barroco. Dentre os autores do teatro Barroco, Calderón de La Barca situa-se, para o filósofo como autor central da estética barroca do século XVII. Porém, antes de entrarmos nas peculiaridades estéticas que determinam o autor espanhol como modelo da produção barroca, é necessário uma explanação de como Benjamin define o gênero Drama Trágico.

Primeiramente, Trauerspiel na etimologia alemã, compõe-se da aglutinação de dois termos, trauer. luto e spiel: jogo, embora Trauerspiel tenha sido traduzido como drama trágico, ao pé da letra, poderíamos tê-lo como "peça enlutada" ou "elegia", a saber, uma poesia originalmente, na Grécia, dedicada ao luto, uma das constantes na temática estética do Barroco.

O livro benjaminiano Origem do drama trágico alemão, escrito entre os anos de 1924 e 1925, originalmente apresentado como tese de Habilitation na Universidade de Frankfurt e recusado pela banca, constitui-se enquanto uma obra sobre um gênero literário - as peças teatrais da Alemanha do século XVII ignoradas pelos demais - e apresenta uma crítica as teorias da tragédia em voga na Alemanha, sobretudo, às teorias de Goethe, Schiller, Hegel, Schelling, Nietzsche e Schlegel. O livro destaca-se pela sua pluralidade interdisciplinar, podendo ser lido como um ensaio filosófico sobre arte, um ensaio sobre a escrita filosófica, portanto como metafilosofia, ou até mesmo, como uma alegoria da situação da República de Weimar. Para o filósofo, é justamente nas peças obscuras - relegadas ao esquecimento e distantes das obras primas -, nessas ruínas da escrita, que a cultura de uma época encontra a sua expressão mais transparente, segundo Benjamin, "uma coisa é encarnar uma forma, outra é dar-lhe uma expressão própria. Se a primeira é atributo dos autores da eleição, a segunda acontece, muitas vezes de forma incomparavelmente mais significativa nas laboriosas tentativas de escritores mais fracos". ${ }^{33}$

Benjamin busca diferenciar a concepcão do drama trágico dos moldes instituídos pelas poéticas normativas, donde as peças do drama trágico alemão sempre cairiam em descredito por não se enquadrarem nas linguagens determinantes das poéticas normativas, estas por sua vez, advindas da Poética de Aristóteles, onde a tragédia seria vista como um gênero natural, seguindo regras específicas para sua composição alcançaria o telos que seria a produção da catarse, ou a purificação das emoções. Já no Idealismo Alemão, apresenta uma teoria metafisica da condição humana, onde a obra de arte trágica funcionaria como orgánon do conhecimento. A importante diferença do Idealismo Alemão em relação às poéticas normativas, a saber, é a introdução, realizada por Schelling, do conceito de trágico, segundo Peter Szond (2004), em O ensaio sobre o trágico, "desde Aristóteles há uma
33. BENJAMIN. Origem do drama trágico alemão, p. 52
EM TESE
BELO HORIZONTE
v. 19
N. 1
JAN.-ABR. 2013
FREITAS. Observações acerca da peça de Pedro Calderón de La Barca [...]
P. $247-261$

\section{Crítica Literária, outras Artes e Mídias}


34. SZONDI. Ensaio sobre o trágico, p. 23.

35. SZONDI. Ensaio sobre o trágico, p. 31.

36. BENJAMIN. Origem do drama trágico alemão, p. 56. poética da tragédia; apenas desde Schelling, uma filosofia do trágico. Sendo um ensinamento acerca da criação poética, o escrito de Aristóteles pretende determinar os elementos da arte trágica; seu objeto é a tragédia, não a ideia de tragédia”. ${ }^{34}$

O conceito de trágico caracterizaria, sobretudo, pelo duelo entre a liberdade do sujeito e a necessidade objetiva, onde

o herói trágico, na interpretação de Schelling, não só sucumbe ao poder superior do elemento objetivo como também é punido por sua derrota, ou simplesmente pelo fato de ter optado pela luta, volta-se contra ele próprio o valor positivo de sua atitude, a vontade de liberdade que constitui "a essência de seu eu" ${ }^{35}$

Para Benjamin, a concepção idealista da tragédia como metafisica da condição humana - nesta concepção o filósofo enquadra a visão nietzschiana da tragédia - erra ao não considerar a historicização do gênero trágico. Segundo o filósofo, o principal objeto do drama trágico é a historia, ou melhor, "a vida histórica, tal como aquela época a concebia é o seu conteúdo, o seu verdadeiro objeto" ${ }^{36}$, diferindo-se, deste modo, da tragédia que tem como objeto, o mito.

O pano de fundo da construção destes dramas são as guerras religiosas. A igreja católica encontrava-se em crise pela perda de fiéis para a religião protestante, e necessitava de uma reação contrária ao movimento que buscava a reforma

EM TESE dos dogmas religiosos, como resposta a este movimento, a igreja apresentava o Barroco, contrapondo à ideia de reforma "a ideia da catástrofe". ${ }^{37}$ Onde, o homem afastado de Deus, ao proclamar-se como Deus nos ideários do Renascimento, adentraria em um confronto entre a phýsis sagrada e a phýsis profana. De modo que, o Renascimento em confronto com o Barroco, "não surge como uma época de irreligião e paganismo, mas como uma era de liberdade profana na vida da fé". ${ }^{38}$ Por sua vez, o Barroco revela que o mundo está abandonado, apresentando ao homem dominado pela culpa da perda de seu estado de graça, a história como imanência e a visão de um mundo em ruínas, cujo emblema principal é a caveira, negando ao homem barroco o "acesso imediato à transcendência”. ${ }^{39}$

O drama trágico constituindo-se enquanto representação da imanência histórica carregado pela culpa adota para si a exigência de desenvolver os anseios teológicos da época, dentre eles, segundo Benjamin, resultante da ausência de redenção, ou seja, de uma teoria sobre os fins últimos do homem, "é a tentativa de encontrar consolo para a renúncia do estado de graça através de um retorno ao estado original de criação". ${ }^{40}$

A temática do drama barroco se passa na vida na corte, os personagens apresentam-se em sua condição régia, "o soberano representa a história” ${ }^{41}$ É justamente, na figura deste
37. BENJAMIN. Origem do drama trágico alemão, p. 60.

38. BENJAMIN. Origem do drama trágico alemão, p. 76.

39. BENJAMIN. Origem do drama trágico alemão, p. 76

40. BENJAMIN. Origem do drama trágico alemão, p. 77.

41. BENJAMIN. Origem do drama trágico alemão, p. 59.

\section{Crítica Literária, outras Artes e Mídias}


soberano que serão encarnados os exemplos de virtudes a serem seguidos e os vícios a serem combatidos. Porém, este soberano também é criatura, e como tal "é o espelho cuja moldura, e só nela, o mundo moral se apresentava ao Barroco" 42 e a corte se apresenta como o cenário natural do processo histórico, no sentido em que os personagens régios visam refletir às máximas morais, políticas e a própria história em sua condição não transcendental.

Nas figuras da corte, em especial na do príncipe e do intriguista, podemos iniciar as comparações que revelam as proximidades entre as máximas do drama trágico do Barroco desenvolvidas pelo filósofo e a peça calderoniana. Segundo Benjamin, o príncipe deve desenvolver "todas as virtualidades do Estado", ${ }^{43}$ o propósito de Calderón dedicado ao personagem Segismundo, de A vida é sonho, é justamente este, apresentar o príncipe como um modelo de virtude que todos os cidadãos do Estado devem seguir. Segismundo tornaria-se, ao evitar as conspirações contra o seu pai e a divisão do reino em guerra civil, o exato modelo de prudência que o governante e os súditos deveriam seguir, ignorando os desejos de cobiça e demonstrando que as boas ações na vida terrena apresentam o caminho prudente a seguir para alcançar o reino dos céus, culminando na celebre máxima que atesta para a principal doutrina a ser ensinada pela peça, não entregar-se às ilusões da realidade terrena, pois "a vida é sonho" ${ }^{44}$ Deste modo, a função do personagem régio, neste caso Segismundo, relaciona-se diretamente com a colocação de que "as máximas didáticas e de reflexão são como pilares do drama trágico; mas não devem ser ditas por criados e pessoas de baixa extração, mas tão somente por pessoas mais nobres e idosas". ${ }^{45}$

O personagem de Clotaldo, que na visão benjaminiana poderíamos aproximá-lo da figura do intriguista, que ao lado do rei Basílio, teria o conhecimento de todos os acontecimentos da trama, sendo ele, aquele que "marca o ritmo dos segundos que capta e fixa o curso dos acontecimentos políticos" ${ }^{\prime 6}$ ao pôr em prática todo o andamento da trama orquestrada pelo rei. Podemos atestar o domínio de Clotaldo sobre o curso político dos acontecimentos em duas passagens da peça, a primeira no início da segunda jornada, onde Clotaldo, ou melhor, o intriguista, prepara a trama real:

CLOTALDO - Tudo feito conforme ordenaste. Com a agradável bebida com tantas ervas mandaste preparar, desci à estreita prisão de Segismundo. A fim de que se encorajasse a empresa que solicistas, falei com ele sobre a presteza de uma águia vertiginosa que, desprezando a rosa dos ventos, passava a ser na altitude suprema do fogo um raio de pluma ou um cometa de liberdade. Ele não precisa de mais; [...] Coloquei-o
44. CALDERÓN DE LA BARCA. $A$ vida é sonho, p. 73.

45. BENJAMIN apud HARDORFFER. Origem do drama trágico alemão, p. 211.

46. BENJAMIN. Origem do drama trágico alemão, p. 97. $\begin{array}{llllll}\text { EM TESE } & \text { BELO HORIZONTE } & \text { v. } 19 & \text { N. } 1 & \text { JAN.-ABB. } 2013 & \text { FREITAS. Observações acerca da peça de Pedro Calderón de La Barca [...] }\end{array}$

\section{Crítica Literária, outras Artes e Mídias}


47. CALDERÓN DE LA BARCA. $A$ vida é sonho, p. 50

48. CALDERÓN DE LA BARCA. $A$ vida é sonho, p. 71. numa carruagem e levei-o até o teu quarto, preparado como majestade e grandeza que a sua pessoa merece. ${ }^{47}$

Orquestrado o ardil, Clotaldo questiona o rei sobre a verdadeira intenção da trama, e assim, descobre os verdadeiros intuitos reais. A outra passagem que revela o domínio de Clotaldo sobre o curso dos acontecimentos dá-se no conselho do intriguista dado para Segismundo, já de volta ao cárcere, no fim da segunda jornada:

CLOTALDO - Como antes de adormeceres havíamos falado sobre as águias, tu, dormindo, sonhaste grandezas impossíveis. Mas teria sido bom que, mesmo em sonhos, pudesses honrar quem te criou com tantos cuidados, Segismundo. Até em sonhos não se perdem as boas ações. ${ }^{48}$

Nesta passagem, revela-se, não somente, a participação efetiva de Clotaldo na trama real, como a sua intervenção direta no curso dos acontecimentos, onde o velho intriguista reforça o entendimento de que o acontecimento que Segismundo acabará de vivenciar, nada mais foi do que um sonho. Ademais, a passagem corrobora para o forte papel didático da peça de Calderón, atribuindo que até mesmo em sonhos, tens de se realizar as boas ações, não se deixando levar pelos excessos ou poderes de sua condição.
Para Benjamin, "é em Calderón que podemos estudar o drama trágico do Barroco na sua forma mais acabada", ${ }^{49}$ pelo fato de que nas peças calderonianas as duas esferas do barroco - a esfera do luto, ocasionada pela perda da situação paradisíaca e pela queda na condição criatural, e a esfera do jogo como produto desta condição sem possibilidade de escatologia - são harmonizadas através da forma lúdica de Calderón que representa a resolução positiva dos conflitos.

O Barroco de Calderón enquadra-se como um jogo desenvolvido na esfera do espetáculo, assumindo a possibilidade de, através da irrealidade deste espetáculo, ser apontada uma ponta de escatologia no destino do personagem, como no exemplo de Segismundo, que após o desenlace das três jornadas redime-se de seus maus feitos e rompe com os efeitos da profecia. $\mathrm{O}$ jogo pode ser visto "também como calculista e planeado, pensado por marionetas cujos fios são manipulados pelo desejo e pela ambição, ${ }^{50}$ é justamente, esta visão que podemos notar no motivo calderoniano acerca de Segismundo, as "marionetas" que planejam a trama do príncipe são, sobretudo, Basílio e Clotaldo, que tendem a estabelecer um jogo, mas que, no entanto, estão sendo manipulados, justamente, pela tentativa de cumprir uma profecia do destino.

É evidente que o desenrolar da peça de Calderón inicia-se das demandas dos presságios que assustam o rei Basílio,
49. BENJAMIN. Origem do drama trágico alemão, p. 78.

50. BENJAMIN. Origem do drama trágico alemão, p. 81.
EM TESE
BELO HORIZONTE
v. 19
N. 1
JAN.-ABR. 2013
FREITAS. Observações acerca da peça de Pedro Calderón de La Barca [...]
P. $247-261$

\section{Crítica Literária, outras Artes e Mídias}


51. SZONDI. Ensaio sobre o trágico p. 96.

52. BENJAMIN. Destino e Caráter. Escritos sobre mito e linguagem p. 94. a saber, do cumprimento da profecia evidenciada oniricamente e astrologicamente, segundo a qual, o destino de seu primogênito era tornar-se o mais cruel dos reis da Polônia, dividindo o reino e semeando os vícios e as discórdias entre os súditos. A crença de Basílio na efetivação do destino de Segismundo é tamanha que para superar a efetivação da profecia decide aprisioná-lo em uma torre, para Peter Szondi "a famosa capacidade do rei de ler o futuro nas estrelas transforma-se, depois de ter sido o fundamento de sua grandeza, em aniquilamento: 'Para os infelizes/ até o mérito é faca,! pois quem se prejudica com o saber,! é homicida de si mesmo!"”.

Walter Benjamin, revela no ensaio "Destino e Caráter", que "o destino se mostra portanto quando se considera a vida de um condenado, no fundo, uma vida que primeiro foi condena e por isso tornou-se culpada", ${ }^{52}$ é este o caso de Segismundo que antes mesmo do nascimento já estava condenado, tornou-se culpado devido a interpretação dos presságios astrológicos do rei, e na forma dos sonhos de sua mãe, a qual:

muitíssimas vezes

entre ideias e delírios

sonhou que ele rompia

suas entranhas, atrevido
[...]

e por seu sangue tingido

dava morte à sua mãe..$^{53}$

Sendo assim, a profecia dos astros e dos sonhos determina a vida do príncipe polonês carregada pela culpa. Porém, segundo Peter Szondi as fontes da profecia "se contradizem" ocasionando o enfraquecimento do valor institucional da profecia. ${ }^{54}$ Ademais, o contexto em que se desenvolvem a peça e a profecia, difere-se do contexto habitual em que se desenvolve a tragédia clássica, ao invés do domínio da profecia ser o da natureza, ela se insere no domínio da história, característica comum dos dramas do Barroco. A própria configuração barroca da peça calderoniana, inserida no contexto religioso cristão, corrobora para o enfraquecimento e questionamento da profecia, e, portanto, do próprio caráter do trágico, de modo que

a tragicidade do destino característica da Antiguidade torna-se, no âmbito cristão, uma tragicidade da individualidade e da consciência. [...] O herói do drama católico torna-se, diante da salvação, vítima de sua tentativa de usar o saber e o pensamento para substituir a realidade ameaçadora por uma outra que ele mesmo cria. ${ }^{55}$
53. CALDERON DE LA BARCA. $A$ vida é sonho, p. 45.

54. SZONDI. Ensaio sobre o trágico, p. 95.

55. SZONDI. Ensaio sobre o trágico, p. 99.

\section{Crítica Literária, outras Artes e Mídias}


56. SZONDI. Ensaio sobre o trágico, p. 99.

57. SZONDI. Ensaio sobre o trágico p. 99-100.
Esta substituição do caráter trágico é evidente nas três jornadas da peça de Calderón, na primeira jornada, ocorre à substituição da tragicidade da profecia pela tragicidade do próprio rei Basílio, que se torna o algoz de Segismundo. A segunda jornada, "configura a tragicidade do esforço para agir sobre a vida de um outro por meio de uma reação planejada e não por uma ajuda compassiva", ${ }^{56}$ ou seja, as ações de Basílio e Clotaldo na tentativa de controlar a vida de Segismundo, tornando-o inofensivo incapaz de cumprir a profecia, acabam por determina-lo como um perigo. E, por fim, na terceira jornada "antes que a obra abandone o âmbito do trágico, como em toda a dramaturgia cristã, finalmente aparece a tragicidade do teste" ${ }^{57}$ sendo assim, a tragicidade final encontra-se no teste a que Segismundo é submetido realizar ou não uma rebelião contra o trono de Basílio, cair na trama do destino ou superá-lo através de seu caráter prudente. É notável que ao superar o destino profético que lhe era reservado, Segismundo determina a potência do bom caráter, obtido através do livre-arbítrio, sobre a determinação do destino.

\section{REFERÊNCIAS}

BENJAMIN, Walter. Drama Trágico e Tragédia; Alegoria e Drama Trágico. In: Origem do drama trágico alemão. Trad. João Barrento. Belo Horizonte: Autêntica, 2011, p. 49-166; 167-253.
BENJAMIN, Walter. Destino e Caráter. In: ___. Escritos sobre mito e linguagem. Trad. Susana Kampff Lages e Ernani Chaves. São Paulo: Editora 34, 2011, p. 89-99.

CALDERÓN DE LA BARCA, Pedro. A vida é sonho. Trad. Renata Pallottini. São Paulo: Hedra, 2009

DESCARTES, René. Meditação Primeira: Das coisas que se podem colocar em dúvida. In: Meditações metafísicas. Trad. Maria Ermantina Galvão. São Paulo: Martins Fontes, 2000, p. 29-39.

LIMA, Luís Filipe; VALLE, Ricardo. Introdução. In: CALDERÓN DE LA BARCA, Pedro. A vida é sonho. Trad. Renata Pallottini. São Paulo: Hedra, 2009, p. 9-29.

SZONDI, Peter. Ensaio sobre o trágico. Trad. Pedro Süssekind. Rio de Janeiro: Jorge Zahar Ed., 2004, p. 27-101.

\section{Crítica Literária, outras Artes e Mídias}

